\title{
In memory of Professor Dr. Béla Szende (1936-2019)
}

\author{
Ursula Rokitansky-Tilscher
}

Received: 28 April 2020 / Accepted: 3 May 2020 / Published online: 26 May 2020

(c) Springer-Verlag GmbH Austria, ein Teil von Springer Nature 2020

We were shocked and deeply saddened to learn of the sudden passing of Dr. Béla Szende (Fig. 1), whom we recently had the privilege of meeting at the Sixth International Meeting on the History of Medicine \& Pathology in Vienna. Sadly, his paper on the influence of Hungarian doctors on the Vienna School of Medicine was to be his last. With his dignified and unassuming manner, this distinguished, wise and clever gentleman left a profound impression on all who met him.

We are extremely grateful to Dr. Attila Zalatnai from the 1st Department of Pathology and Experimental Cancer Research, and General Secretary of the Hungarian Society of Pathologists for having provided the following biographical information about this outstanding scientist and human being.

Béla Szende committed himself to the science of pathology more than sixty years ago, when he began his studies at the First Department of Pathology and Experimental Cancer Research at the Semmelweis Medical University, Budapest. Later, at the pinnacle of his career, he was proud to serve as its head and director. In our modern, over-specialized world, he was one of the few whose knowledge spanned the entire spectrum of pathology; there were no aspects of this science with which he was not familiar. He gained recognition early on from his colleagues who turned to him with diagnostic problems from all over the country. His influential textbook, Introduction to Histopathology (also published in English), was used by hundreds of medical students, the volume on Cases in Clinicopathology enriched our diagnostic capacities across the entire spectrum of medicine. It is thanks to

\section{Dr. med. U. Rokitansky-Tilscher $(\bowtie)$}

Kommission für Geschichte und Philosophie der Wissenschaften, Arbeitsgruppe Geschichte der Medizin, Österreichische Akademie der Wissenschaften, Vienna, Austria

ursula.rokitansky@a1.net the exceptional reorganization of our museum collection under his auspices that it still forms the basis for the training of pathologists, especially as regards histology. Besides high-level work in classical pathology, he displayed a keen interest in novelties that were not at first received with enthusiasm by many, but which

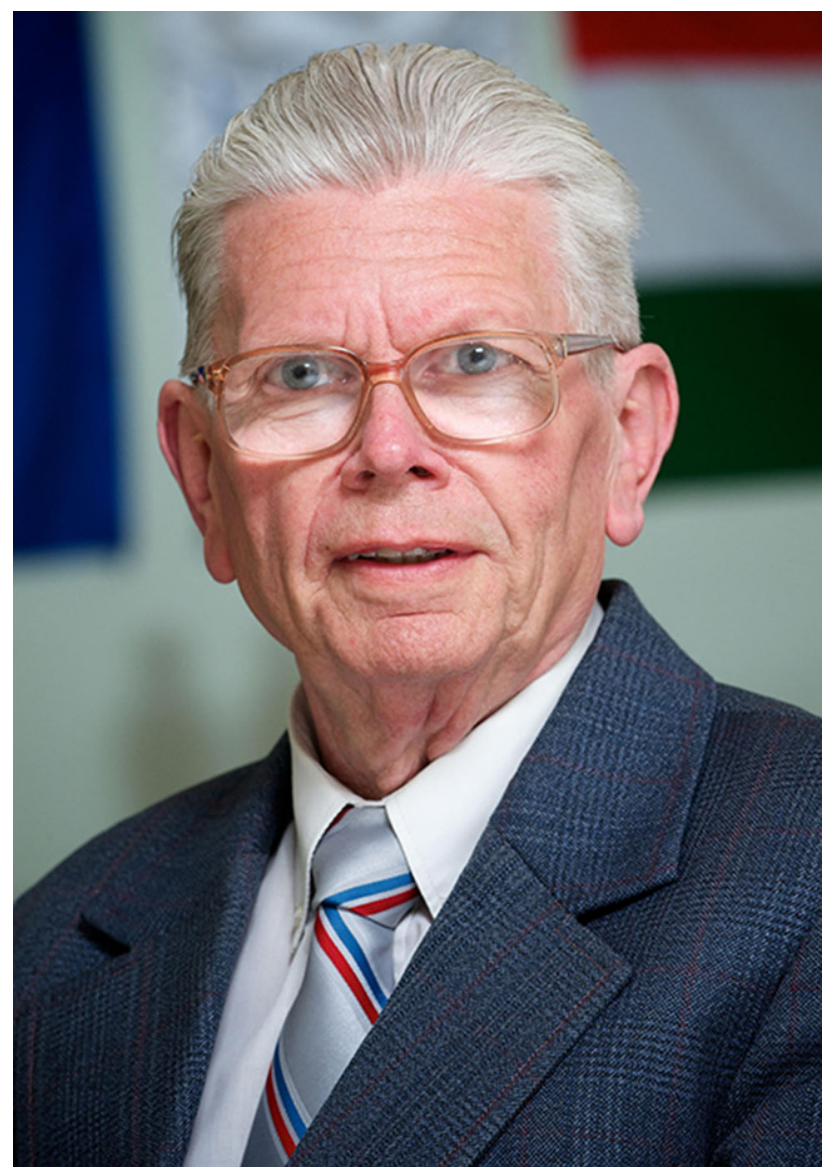

Fig. 1 Em. Prof. Dr. Béla Szende 
Scientific activities collected in the Journal of the Hungarian Medical Chamber (Orvosok Lapja. A Magyar Orvosi Kamar hivatalos folyóirata 2019/4, p. 31)

1. First publication about pneumoconiosis caused by inhalation of PVC microparticles.

2. Research and book on mediastinal tumours.

3. Detection of HLA-DR in the epithelial cells of cholangial hepatic ducts in case of transplanted organ rejection.

4. Detection of HHV8 in Kaposi's sarcomas developed after organ transplantation.

5. Amino acids: the influence of D-L antagonism on growth of tumours, the biological effects of trimethyl lysine and methyl arginine.

6. Apoptosis as a consequence of hormonal effects, GNRH, clinical observations (8 PhD dissertations).

7. Signal transmission: TK blockers, the third type of programmed cell death.

8. The dose-dependent anti- or pro-apoptotic effect of deprenyl.

9. The dose-dependent biological effects of the laser beam, formaldehyde and resveratrol.

10. Telepathology, digital pathology

11. Experimental toxicology

12. History of medical science. Book (with Katalin Szabó): Aere perennius. More Lasting than Bronze. Eponymous Hungarian physicians and their contributions and inventions. Budapest, 2013 and 2018.

13. The rules of medical ethics (Hungarian Medical Chamber).

proved their value in time, such as the use of laser beams for the healing of wounds. Another such discovery was that the tumour-inhibiting effects of hormonal treatments work by way of apoptosis, an idea that initially also met with resistance but which eventually became the starting point of all apoptosis-related research at our institute. He was one of the first to introduce microwaves in histological technology, he prompted our institute to become part of the first telepathological network, and it was on his initiative that the computerized storage of autopsy records and diagnoses was introduced.

His experimental research also enriched scholarship with several new results, although he was always very modest about these. His insights were accurate; in discussions he used logical reasoning to promote his argument, but he was equally open to counter arguments. We never saw him at rest; he was full of ideas and energy. He taught, mentored, attended congresses, supervised $\mathrm{PhD}$ dissertations, was an active member of the committees of the Hungarian Academy of Sciences and president of the university's panel on pathology. He gained everlasting merits as the president of the Ethical College of the Hungarian Medical Chamber. After his retirement he continued to teach the German medical and dental students, wrote research papers, and even if he visited the institute less frequently, he remained involved with its everyday life and followed its activities with interest.

Under his leadership, the institute established close relations with the Pathology Department of the University of Marosvásárhely (Târgu Mureș), and through his personal contacts, our institute-and Hungarian pathology in general-benefited greatly from the professional training offered by Professor Károly Balogh of Harvard University. Professor Szende was personally acquainted with all our former and recent colleagues, and if we were unable resolve any questions concerning the history of pathology, he was always ready to mobilize his vast knowledge. His appreciation of his predecessors was best shown by those volumes and exhibitions in which he presented the lives of Hungarian physicians whose names have been attached to a remarkable invention or contribution, or whose portraits were cast on medals.

The Hungarian Society of Pathologists (HSP) recognized early on how strongly we could rely on his professional qualities, organizational skills and diplomatic abilities in resolving difficult situations, and he readily took up these challenges. He served as the General Secretary of HSP for ten years, as the chairman of the Professional College for six years and was also a member of the Board of the Professional College of Oncology. He received the highest awards that can be bestowed by the HSP, the Baló- and Romhányi Prizes, and was a holder of state honours such as the Chivalry Cross of the Order of Hungary. He was elected member of several international academic associations, including the Royal Society of Medicine, and his achievements were recognized by the most distinguished journals. He held research fellowships in the UK and the US, as well as in Germany, Austria and Japan.

This long and successful career has ended abruptly. Our duty is to protect and maintain as much as possible of his achievements, and to preserve the memory of our wise master. Not long ago, on his eightieth birthday, he said the following: "One of God's greatest gifts is time, and the possibility to create something useful in it". He lived according to this principle: what he created is not only useful but will stay with us forever. He will be sadly missed and fondly remembered. We extend our heartfelt condolences to his family.

He published numerous articles and held lectures in many countries in Europe, America and Asia on the above-listed topics. 
Conflict of interest U. Rokitansky-Tilscher declares that she has no competing interests.

Publisher's Note Springer Nature remains neutral with regard to jurisdictional claims in published maps and institutional affiliations. 